\title{
Electrochemical and Metallurgical Behavior of Lead- Magnesium Casting Alloys as Grids for Lead-Acid Batteries
}

\author{
Salma Khatbi", Youssef Gouale, Abdeslam Lamiri and Mohamed Essahli \\ Univ. Hassan 1, Laboratory of Applied Chemistry and Environment, Faculty of Science and \\ Technology, BP 5777, Settat, Morocco \\ *Corresponding author: khatbisalma@gmail.com
}

Received September, 3, 2018; accepted November 8, 2020

https://doi.org/10.4152/pea.2021390403

\begin{abstract}
In order to evaluate the influence of magnesium on the corrosion resistance of lead anodes in $\mathrm{H}_{2} \mathrm{SO}_{4} 4 \mathrm{M}$, as well as on the microcrystalline morphology of lead, different electrochemical and metallurgical studies were made, such potentiodynamique polarization, electrochemical impedance spectroscopy, microhardness evolution, X-ray fluorescence spectroscopy and optical microscopy. The obtained results have shown that the addition of magnesium up to $1.5 \%$ in weight leads to a significant decrease in the corrosion current density $\left(\mathrm{I}_{\text {corr }}\right.$ ) and therefore, it increases the corrosion inhibition efficiency to $83 \%$ and it reduces the famous sulfation phenomena, by facilitating the transformation of $\mathrm{PbSO}_{4}$ and $\mathrm{PbO}$ to $\mathrm{PbO}_{2}$. It also makes the micro-structure of $\mathrm{Pb}$ much stronger, which makes the $\mathrm{Pb}$ anodes more resistant to mechanical shocks within the battery. We have also studied the effect of temperature on the corrosion of the new casting alloys. We found that an increase in temperature led to a decrease in its effect on the corrosion of alloys, compared with that of pure lead. Therefore, the new improved battery is more resistant, durable and more environment friendly.
\end{abstract}

Keywords: battery, corrosion, $\mathrm{Pb}-\mathrm{Mg}$, electro-chemistry.

\section{Introduction}

Pure lead is too fragile to be used alone in the batteries; it corrodes easily by being immersed in $4 \mathrm{M}$ sulfuric acid. Within the battery, the anode of pure lead will lengthen and deform, which makes the layer of $\mathrm{PbO}_{2}$ crack, exposing it to oxidation and also to an accelerated corrosion, which has been proven by A. Felder and R. D. Prengaman [1]. The lead-acid batteries also suffer from the sulfation phenomenon, which is the formation of $\mathrm{PbSO}_{4}$ covering the surface of lead and preventing the electrochemical reactions to occur, thus reducing the length of the battery life [2]. It is for these reasons that a lot of researches have recently been made to develop some alloys based on lead, which have better corrosion resistance and better hardness, allowing the battery to last longer. Some researchers have chosen to add some chemical products into the electrolyte of the battery, e.g., there are phosphorus compounds, such as phosphoric acid and its 
salts, which have given some very remarkable results, when it comes to decrease the appearance of the sulphation phenomenon [3-5].

Many researches have recently been made to find the best alloys capable of replacing the pure lead plates. Wislei $\mathrm{R}$. Osorio et al [6] have found that the $\mathrm{Pb}-1 \%$ $\mathrm{Sn}$ and $\mathrm{Pb}-2.5 \% \mathrm{Sn}$ alloys immersed in $0.5 \mathrm{M} \mathrm{H}_{2} \mathrm{SO}_{4}$ considerably reduce lead corrosion, when these alloys have coarse grains, in comparison with other alloys that have finer grains. Also, this type of alloys allows to make much lighter batteries. M. I. C`ekerevac et al [7] and R. David Prengaman [8] have studied the influence of the addition of tin and silver on $\mathrm{Pb}$ corrosion rate, by modifying its micro-structure. They have found that, indeed, the $\mathrm{Pb}-\mathrm{Ca}-\mathrm{Sn}-\mathrm{Ag}$ alloy is more resistant to corrosion, in comparison with pure $\mathrm{Pb}$, and that by increasing the concentration of the added $\mathrm{Sn}$ and $\mathrm{Ag}$, the micro-structure of the primary alloy $\mathrm{Pb}$ $\mathrm{Ca}$ is modified in a positive way. L. Albert and $\mathrm{Al}$ [9] have found that, when $\mathrm{Sn}$ is added up to $1.2 \%$ in weight, the passivation rate of the $\mathrm{Pb}-\mathrm{Ca}-\mathrm{Sn}$ alloys decrease, under conditions that simulate the deep discharge of the battery, by increasing the conductivity of the $\mathrm{PbO}$ layer that is usually formed on the metal surface. Very little researches have been done to evaluate the effect of the addition of aluminum on lead corrosion in batteries, and, for this reason, we chose aluminum to be our element of addition.

Prior to this work, we assessed the effect of the addition of chemical compounds containing phosphorus on lead corrosion, and it has been proved that these elements significantly reduce lead corrosion rate in batteries [11]. We also studied the electrochemical and metallurgical effect of aluminum on lead corrosion in $4 \mathrm{M}$ $\mathrm{H}_{2} \mathrm{SO}_{4}$; we found that aluminum added up to $1.5 \%$ in weight leads to an increase in the micro-hardness of $\mathrm{Pb}-\mathrm{Al}$ alloys, reduces the corrosion current density ( $\left.\mathrm{I}_{\text {corr }}\right)$ and decreases $\mathrm{Pb}$ corrosion rate by $51.15 \%$ [12].

Therefore, the present work focused on a new alloy that has never been investigated for the improvement of the lead-acid battery. We chose to study the effect of $\mathrm{Mg}$ content on certain mechanical properties, e.g., micro-hardness, microstructural, electrochemical and corrosion behaviour of synthetic $\mathrm{Pb}-\mathrm{Mg}$ alloys prepared in our laboratory. The results were compared with those of pure $\mathrm{Pb}$ in a 4 $\mathrm{M} \mathrm{H}_{2} \mathrm{SO}_{4}$ solution. Tafel polarization and electrochemical impedance spectroscopy (EIS) techniques were used to study the electrochemical behaviour of the alloy in $4 \mathrm{M} \mathrm{H}_{2} \mathrm{SO}_{4}$.

\section{Experimental}

\section{Material}

A stock solution of $4 \mathrm{M} \mathrm{H}_{2} \mathrm{SO}_{4}$ acid (the acid used in the lead/acid battery) was prepared by dilution of the calculated volume of A.R. grade acid. $\mathrm{Pb}$ and $\mathrm{Mg}$ of high purity (99.999\%) were used to prepare $\mathrm{Pb}-\mathrm{Mg}$ alloys as disk electrodes (A $=1 \mathrm{~cm}^{2}$ ) in a Gallenkamp muffle furnace, using evacuated closed silica tubes, at $603 \mathrm{~K}\left(330^{\circ} \mathrm{C}\right)$, for $20 \mathrm{~min}$.

The melts were shaken every $5 \mathrm{~min}$ to ensure the homogeneity of the melting alloys. Finally, the melts were quenched in cold water $\left(10^{\circ} \mathrm{C}\right)$, in order to obtain a 
supersaturated solid solution. Four samples of $\mathrm{Pb}-\mathrm{Mg}$ alloys with different $\mathrm{Mg}$ contents $(0.5,0.8,1$ and $1.5 \% \mathrm{wt})$ were prepared with the same procedure.

The temperature, as well as $\mathrm{Mg}$ percentages, were chosen based on the phase diagram of $\mathrm{Pb}-\mathrm{Mg}$ alloys (Fig. 1). The investigated alloys were analyzed using the Thermo Scientific Niton XL5 X-ray fluorescence spectrometer. For each alloy, the percentage of $\mathrm{Pb}$ and $\mathrm{Mg}$ was found in accordance with the percentage of the $\mathrm{Pb}$ and $\mathrm{Mg}$ mixture.

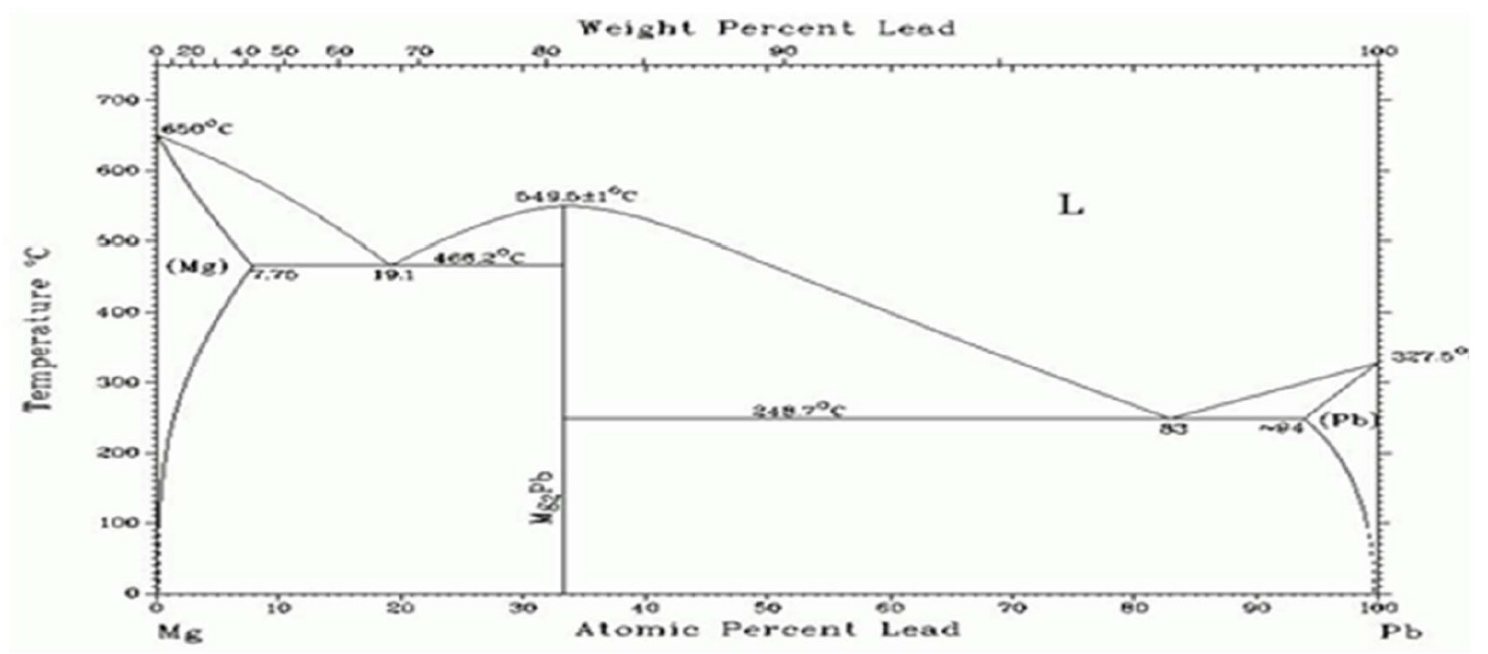

Figure 1. Phase diagram of $\mathrm{Pb}-\mathrm{Mg}$ alloys.

The composition of lead with different contents of $\mathrm{Mg}$ is represented in Table 1.

Table 1. Chemical compositions of pure $\mathrm{Pb}$ and $\mathrm{Pb}-\mathrm{Mg}$ samples.

\begin{tabular}{ccccccccc}
\hline $\begin{array}{c}\text { Mg added } \\
(\%)\end{array}$ & $\begin{array}{c}\text { Pb } \\
(\mathbf{\%})\end{array}$ & $\begin{array}{c}\mathbf{M g} \\
(\mathbf{\%})\end{array}$ & $\begin{array}{c}\text { Sn } \\
(\mathbf{\%})\end{array}$ & $\begin{array}{c}\text { Si } \\
(\mathbf{\%})\end{array}$ & $\begin{array}{c}\mathbf{P} \\
(\mathbf{\%})\end{array}$ & $\begin{array}{c}\mathbf{C r} \\
(\mathbf{\%})\end{array}$ & $\begin{array}{c}\text { Al } \\
(\mathbf{\%})\end{array}$ & $\begin{array}{c}\mathbf{Z n} \\
(\mathbf{\%})\end{array}$ \\
\hline $\mathbf{0}$ & 99.890 & ---- & 0.050 & ---- & 0.058 & 0.002 & ---- & ---- \\
\hline $\mathbf{0 . 5}$ & 99.498 & 0.500 & 0.001 & 0.000 & ---- & ---- & 0.001 & ---- \\
\hline $\mathbf{0 . 8}$ & 99.100 & 0.800 & 0.002 & ---- & 0.093 & 0.0008 & ---- & 0.004 \\
\hline $\mathbf{1}$ & 98.893 & 1.000 & 0.002 & 0.086 & 0.010 & 0.009 & ----- & ---- \\
\hline $\mathbf{1 . 5}$ & 98.447 & 1.500 & ---- & 0.027 & ---- & 0.0001 & 0.025 & 0.0008 \\
\hline
\end{tabular}

\section{Optical microscopy}

The physical properties of the quenched solid solutions of lead alloys evolve at room temperature $\left(25{ }^{\circ} \mathrm{C}\right)$. The hardening mechanisms are continuous/discontinuous transformations.

In fact, this temperature corresponds to $0.5 \mathrm{Tf}$ (alloy's melting temperature). We know that from 0.4 to $0.5 \mathrm{Tf}$, the alloy elements can diffuse. In the case where the kinetics of the discontinuous transformation is rapid at room temperature, we have used the original technique developed by Hilger [13], in order to be able to observe the structure before any transformation.

For our alloys, the sample was polished and soaked in a chemical solution consisting of one part of $30 \% \mathrm{H}_{2} \mathrm{O}_{2}$ and three parts of glacial acetic acid. The solution temperature was $-50{ }^{\circ} \mathrm{C}$. The duration of the immersing process varied between $20 \mathrm{sec}$ and $2 \mathrm{~min}$, depending on the state of the sample. The chemical 
polishing was followed by repeated chemical attacks/etching using a mixture of $100 \mathrm{~mL}$ distilled water, $25 \mathrm{~g}$ of citric acid and $10 \mathrm{~g}$ of ammonium molybdate.

\section{Electrochemical measurements}

For electrochemical measurements, a three-electrode conventional glass cell was used. The experiments were performed in a $250 \mathrm{~mL}$ volume borosilicate glass cell, using a Pt wire and a saturated calomel electrode (SCE) as auxiliary and reference electrodes, respectively. SCE tip was very close to the surface of the working electrode, to minimize the IR drop. All potentials given in this paper are referred to this reference electrode. A flat working electrode surface was obtained by mechanical polishing with emery papers of successively decreasing grain size (1200, 800 and 400). The working electrodes were rinsed with double-distilled water. The electrolyte was a $4 \mathrm{M} \mathrm{H}_{2} \mathrm{SO}_{4}$ solution. To remove any surface contamination and air-formed oxide, the working electrode was kept at $-1.2 \mathrm{~V}$ (SCE), for $10 \mathrm{~min}$, in the tested solution. Then, it was disconnected and shaken free of adsorbed hydrogen bubbles. The potentiodynamic polarization, with a scanning speed of $1 \mathrm{mV} / \mathrm{s}$, began with a potential of $-1.5 \mathrm{~V}$, and ended with a potential of $+2.3 \mathrm{~V}$. The linear Tafel segments of the cathodic and anodic curves were extrapolated to the corrosion potential, to obtain the corrosion current densities ( $\left.\mathrm{I}_{\text {corr }}\right)$. Measurements were conducted at $298 \mathrm{~K}, 313 \mathrm{~K}, 333 \mathrm{~K}$, and $353 \mathrm{~K}$ $\left(25^{\circ} \mathrm{C}, 40^{\circ} \mathrm{C}, 60^{\circ} \mathrm{C}\right.$, and $\left.80^{\circ} \mathrm{C}\right)$, for each investigated electrode.

The measurements of the electrochemical impedance spectroscopy have been carried out using a margin of frequency ranging from $100 \mathrm{kHz}$ to $10 \mathrm{~Hz}$, at the corrosion potential. For the analysis, we used the 10 VoltaLab model (PGZ100) device connected to an HP computer. The acquisition and processing of data were done using VoltaMaster 4 and OriginLab software.

\section{Results and discussion}

\section{Optical microscopy}

The first transformation began during the first sec of ageing at room temperature. The observations show a discontinuous transformation with fronts originating from the grain boundaries and sweeping quickly over the whole surface. Fig. 2 shows the regular progression of the transformation front in the bulk of the grain. When two fronts from two different grains boundaries come together, a new stationary boundary is formed (b). The borders of the cells have a tendency to blur lightly behind the front. This phenomenon could be explained by a reorganization (partial homogenization) of the segregated elements on the boundaries of the solidification cells, during the passage of the transformation.

\section{Micro-hardness}

The hardness values of $\mathrm{Pb}$ and $\mathrm{Pb}-\mathrm{Mg}$ alloys were measured by employing the Vickers micro-hardness test procedure with a Vickers pyramidal indentor. The Vickers hardness number is given by $\mathrm{HV}=0.185 \mathrm{~F} / \mathrm{d}^{2}$, where $\mathrm{F}$ is the applied load and $\mathrm{d}$ is the average diagonal length in millimeters. Each value was an average of, at least, three measurements determined on the surface of the specimens. The data 
in Fig. 3 reveal a non-linear increment of the micro-hardness, with an increase in $\mathrm{Mg}$ content in the alloy. Noteworthy, the $\mathrm{Pb}-1.5 \% \mathrm{Mg}$ alloy almost shows threefold micro-hardness values $(14.6 \mathrm{HV})$, in comparison to those of pure $\mathrm{Pb}(5 \mathrm{HV})$. The micro-hardness of the $\mathrm{Pb}-\mathrm{Mg}$ alloy not only depends on its chemical composition, but it is also significantly affected by the micro-structure array. One can conclude that the increase in micro-hardness with the increasing $\mathrm{Mg}$ alloying can be attributed to grain refinement, as previously shown in optical microscope results.

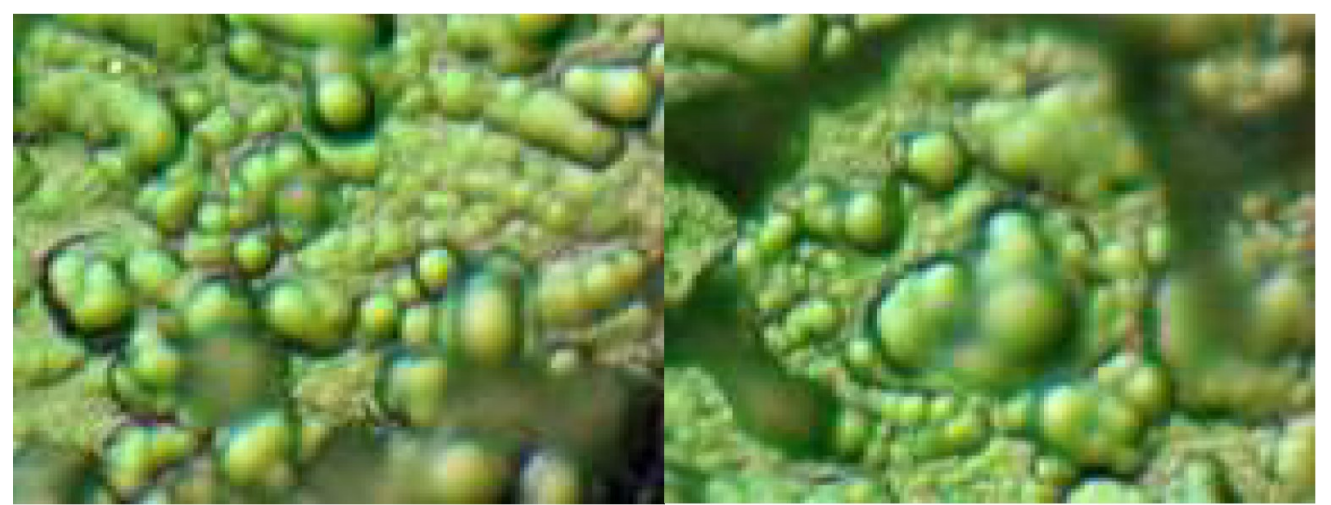

Figure 2. Microstructure of quenched cast $\mathrm{Pb}-1.5 \% \mathrm{Mg}$ alloy at $25^{\circ} \mathrm{C}$. Visualization of the discontinuous transformation (a) after 1 hour (b).and after 1 month

Accordingly, the existence of a certain percentage of $\mathrm{Mg}$ inside $\mathrm{Pb}$ micro-structure would lead to the improvement of its mechanical properties.

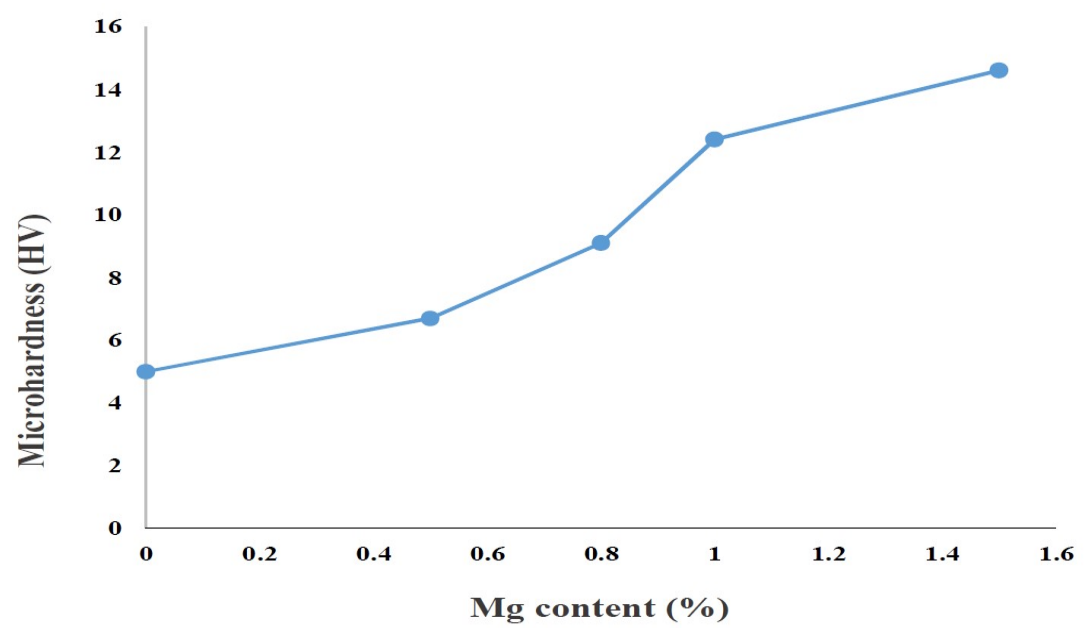

Figure 3. Variation of micro-hardness with magnesium in the specimen.

\section{Electrochemical measurements}

Effect of $\mathrm{Mg}$ concentration: Potentiodynamique polarization

Fig. 4 represents the experimental results from polarization curves of pure $\mathrm{Pb}$ and $\mathrm{Pb}-\mathrm{Mg}$ alloys in $4 \mathrm{M} \mathrm{H}_{2} \mathrm{SO}_{4}$, with a scan rate of $1 \mathrm{mV} / \mathrm{s}$, at $25^{\circ} \mathrm{C}(298 \mathrm{~K})$. Corrosion parameters were calculated on the basis of cathodic and anodic potential vs current density characteristics in the Tafel potential region. The values of the corrosion current density $\left(\mathrm{I}_{\text {corr }}\right)$ for the samples were determined by extrapolation of the cathodic and anodic Tafel lines to corrosion potential ( $\left.\mathrm{E}_{\mathrm{corr}}\right)$ (Table 2). 
There is a marked shift towards lower current densities $\left(\mathrm{I}_{\text {corr }}\right)$, in the case of the investigated $\mathrm{Pb}-\mathrm{Mg}$ alloys, compared with those of pure $\mathrm{Pb}$. However, these shifts were accompanied by a significant decrease in corrosion rates. These shifts were greater as $\mathrm{Mg}$ content was increasing. This indicated that $\mathrm{Mg}$ content in the alloy plays an important role in slowing down $\mathrm{Pb}$ corrosion rate. The two breaks observed in the anodic branch, at a more positive potential (at $\approx 450 \mathrm{mV} / \mathrm{SCE}$ ), can be attributed to the formation of a thick layer of $\mathrm{PbSO}_{4}$ and lead oxide, respectively, on the metal surface in this region. On the other hand, the negative shift in the corrosion potential ( $\left.\mathrm{E}_{\mathrm{corr}}\right)$, with a simultaneous decrease in the corrosion rate of the investigated alloys, compared with that for pure $\mathrm{Pb}$, can be ascribed to $\mathrm{Pb}-\mathrm{Mg}$ phase formation (Fig.4).

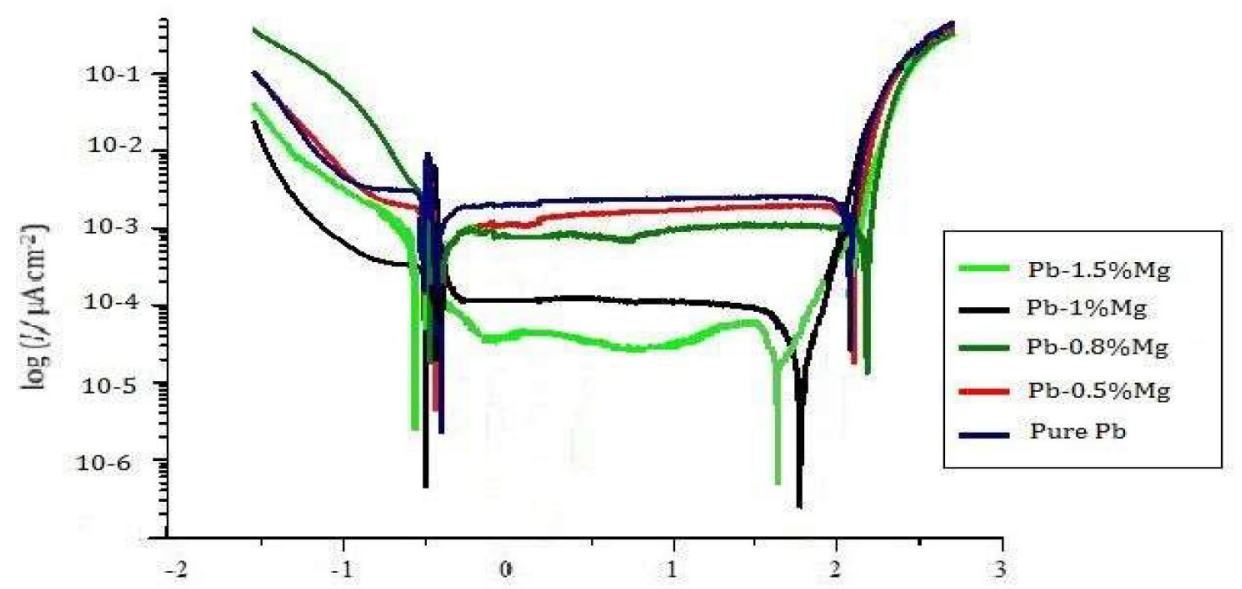

Figure 4. Polarization curves of Pure $\mathrm{Pb}$ and $\mathrm{Pb}-\mathrm{Mg}$ alloys in $4 \mathrm{M} \mathrm{H}_{2} \mathrm{SO}_{4}$, at $25^{\circ} \mathrm{C}$.

Table 2. Corrosion parameters obtained from Tafel Slopes extrapolation for pure $\mathrm{Pb}$ and $\mathrm{Pb}-\mathrm{Mg}$ alloys in $4 \mathrm{M} \mathrm{H}_{2} \mathrm{SO}_{4}$, at $25^{\circ} \mathrm{C}$.

\begin{tabular}{ccccccc} 
Alloy & $\begin{array}{c}\mathbf{E}_{\text {corr1 }} \\
(\mathbf{m V} / \mathbf{S C E})\end{array}$ & $\begin{array}{c}\mathbf{E}_{\mathbf{c o r} 2} \\
(\mathbf{m V} / \mathbf{S C E})\end{array}$ & $\begin{array}{c}\mathbf{I}_{\mathbf{c o r r}} \\
\left(\boldsymbol{\mu} \mathbf{A} / \mathbf{c m}^{2}\right)\end{array}$ & $\begin{array}{c}\mathbf{I}_{\text {pass }} \\
\left(\boldsymbol{\mu} \mathbf{A} / \mathbf{c m}^{\mathbf{2}}\right)\end{array}$ & $\begin{array}{c}\mathbf{E}_{\text {tra }} \\
(\mathbf{m V} / \mathbf{S C E})\end{array}$ & $\begin{array}{c}\text { Corrosion rate } \\
(\mathbf{m m} / \mathbf{y e a r})\end{array}$ \\
\hline pure Pb & -462 & -458 & 349 & 374 & 2362 & 41.62 \\
$\mathbf{P b - 0 . 5 \% M g}$ & -471 & -455 & 300 & 338 & 2425 & 30.14 \\
$\mathbf{P b - 0 . 8 \% M g}$ & -498 & -470 & 274 & 301 & 2450 & 20.92 \\
$\mathbf{P b - 1 \% M g}$ & -500 & -491 & 116 & 132 & 1851 & 8.02 \\
$\mathbf{P b - 1 . 5 \% M g}$ & -573 & -510 & 59 & 82 & 1687 & 3.91 \\
\hline
\end{tabular}

The shift of the alloy corrosion potential to a more negative direction, with the increase in $\mathrm{Mg}$ content, can be attributed to $\mathrm{Mg}$ potential, which is more negative than that of $\mathrm{Pb}$.

In previously published researches [14], it was found that the alloying solidsolution phase on the alloy as a separated phase acts as cathodic site on the alloy surface. Therefore, we can assume that $\mathrm{Mg}$ presence as alloying element decreases the density of active sites on the alloy surface, compared with those of $\mathrm{Pb}$.

Consequently, the alloy dissolution rate decreases in $\mathrm{H}_{2} \mathrm{SO}_{4}$ solution, compared with that of pure $\mathrm{Pb}$. This can explain the shift of $\mathrm{E}_{\text {corr }}$ towards more negative values in $\mathrm{Pb}-\mathrm{Mg}$ alloys, compared to that of pure $\mathrm{Pb}$. 
As shown in Table 2, the corrosion current density $\left(\mathrm{I}_{\text {corr }}\right)$ of $\mathrm{Pb}-1.5 \% \mathrm{Mg}$ is $\mu \mathrm{A} / \mathrm{cm}^{2}$, while that for pure $\mathrm{Pb}$ is $349 \mu \mathrm{A} / \mathrm{cm}^{2}$, at $25^{\circ} \mathrm{C}$. Thus, the addition of $1.5 \%$ of $\mathrm{Mg}$ to $\mathrm{Pb}$ reduced the corrosion rate by $83 \%$ (Fig. 5 ).

This inhibition efficiency $(\mathrm{y})$ was calculated by using the following equation:

$$
\eta=\frac{\mathrm{CR}-\mathrm{CR} \prime}{\mathrm{CR}} \times 100
$$

where $\mathrm{CR}$ is the corrosion rate of pure $\mathrm{Pb}$ and $\mathrm{CR}^{\prime}$ is the corrosion rate of $\mathrm{Pb}$ $\mathrm{Mg}$.

These results indicate that $\mathrm{Mg}$ addition leads to a significant increase in $\mathrm{Pb}$ corrosion resistance. This behaviour can be interpreted based on previous works [15] done on the corrosion of $\mathrm{Pb}$, by assuming that $\mathrm{Mg}$ particles tend to be oriented towards the surface and stay that way during $\mathrm{Pb}$ dissolution. Since the dissolution of crystalline structures typically proceeds layer by layer along the steps, the formation of solid particles along the steps may have an effect of blocking the sites for the dissolution reaction [16]. This argument would be due to

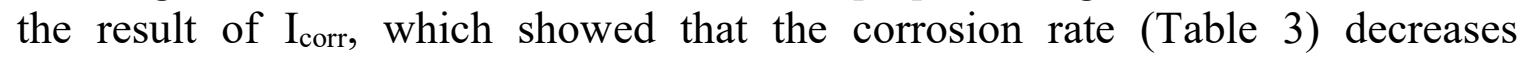
significantly with $\mathrm{Mg}$ addition.

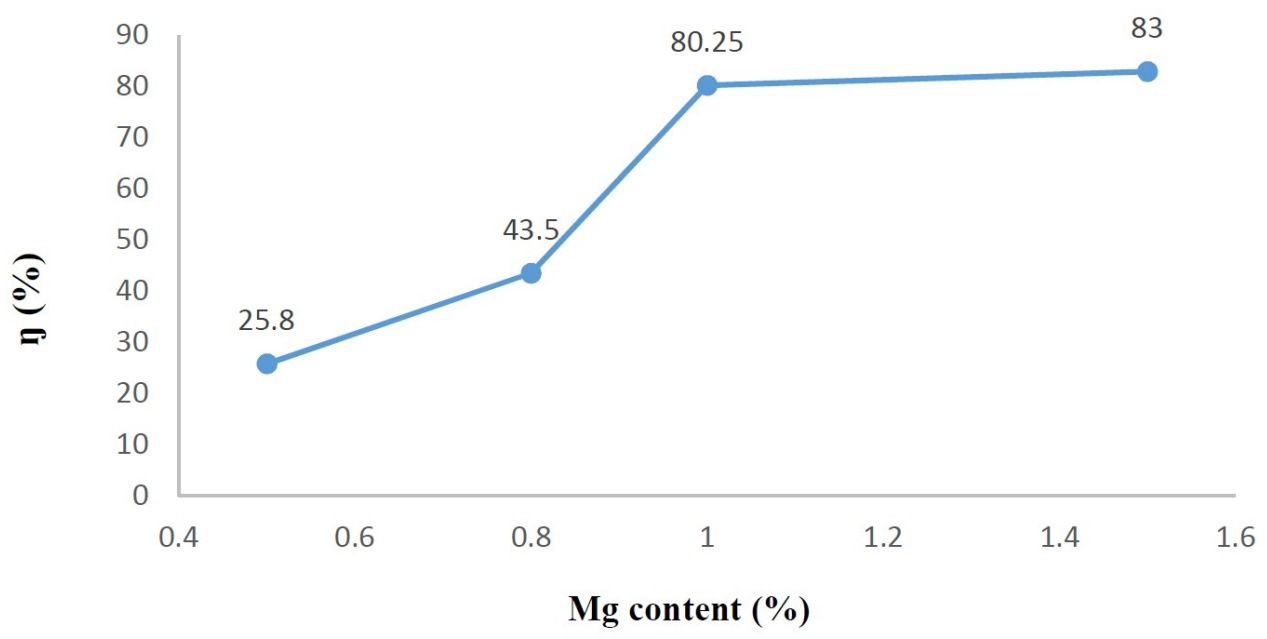

Figure 5. Relationship between $\mathrm{Mg}$ contents and the inhibition efficiency based on potentiodynamique polarization parameters.

We can also notice a decrease in $\mathrm{I}_{\text {pass }}$ with increasing $\mathrm{Mg}$ content. This can be explain by the fact that the formation of the two corrosion compounds $\left(\mathrm{PbSO}_{4}\right.$ and $\mathrm{PbO}$ ) decreases, since $\mathrm{Mg}$ decreases $\mathrm{Pb}$ corrosion rate. Therefore, the size of the thick passive layer decreases by adding $\mathrm{Mg}$, and $\mathrm{I}_{\text {pass }}$ decreases accordingly.

At the anodic potentials, the products of the corrosion $\left(\mathrm{PbO}\right.$ and $\left.\mathrm{PbSO}_{4}\right)$ are transformed into $\mathrm{PbO}_{2}$ by a reaction with sulfuric acid.

This transformation is indicated by a peak of polarization characterized by a potential of transpassivation $\left(E_{\text {tra }}\right)$ followed by an increasing current corresponding to oxygen evolution.

The results show that the addition of $\mathrm{Mg}$ up to $1.5 \%$ leads to a decrease in the $\mathrm{E}_{\text {tra, }}$ meaning that $\mathrm{Mg}$ tends to facilitate the transformation of $\mathrm{PbSO}_{4}$ and $\mathrm{PbO}$ to $\mathrm{PbO}_{2}$. 
This indicates that the phenomenon of sulfation (formation and deposition of lead sulfate) will be reduced, in the case of $\mathrm{Pb}-\mathrm{Mg}$.

Effect of $\mathrm{Mg}$ content: Electrochemical Impedance Spectroscopy (EIS)

The impedance of the pure $\mathrm{Pb}$ and $\mathrm{Pb}-\mathrm{Mg}$ alloys in a $4 \mathrm{M} \mathrm{H}_{2} \mathrm{SO}_{4}$ solution, at the steady state of open-circuit potential $\left(\mathrm{E}_{\mathrm{corr}}\right)$, has been plotted, as shown in Fig. 6. An analysis for the impedance in the examined potential range was carried out. The data of the charge transfer resistance $\left(R_{t}\right)$ and the capacity of the double layer $\left(\mathrm{C}_{\mathrm{dl}}\right)$ were calculated using the Nyquist plot; the values are tabulated in Table 3.

Fig. 6 shows a comparison between the Nyquist plots of pure $\mathrm{Pb}$ and the $\mathrm{Pb}-\mathrm{Mg}$ alloys (from 0.5 to $1.5 \% \mathrm{Mg}$ ), in a $4 \mathrm{M} \mathrm{H}_{2} \mathrm{SO}_{4}$ solution, at $25{ }^{\circ} \mathrm{C}(298 \mathrm{~K}$ ). The Nyquist plots were in the shape of a deformed semicircle. This indicates that the main reaction mechanism present on the double layer is the charge transfer mechanism, and that control of charged species by diffusion is absent [17-18]. Pure $\mathrm{Pb}$ and $\mathrm{Pb}-\mathrm{Mg}$ alloys exhibited similar Nyquist plots in a $4 \mathrm{M} \mathrm{H}_{2} \mathrm{SO}_{4}$ solution. This means that the addition of $\mathrm{Mg}$ to $\mathrm{Pb}$ up to $1.5 \%$ does not change the main reaction mechanism on the metal surface. We can also notice that the increase in the semicircle diameter of all alloys is more than that of pure $\mathrm{Pb}$. The maximum semicircle diameter is obtained in the case of $\mathrm{Pb}-1.5 \% \mathrm{Mg}$ alloy. This behaviour exhibits very important results, showing that $\mathrm{Mg}$ content in the alloy plays an important role in decreasing the corrosion rate in a $4 \mathrm{M} \mathrm{H}_{2} \mathrm{SO}_{4}$ solution. Consequently, the corrosion resistance increases with the increase in $\mathrm{Mg}$ content in the alloy.

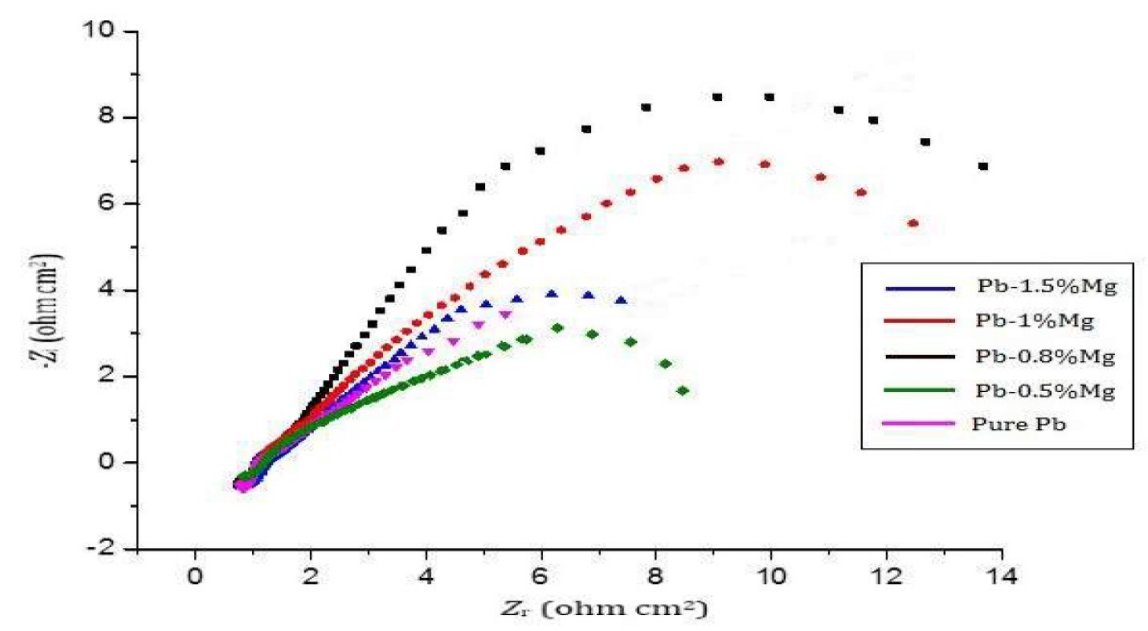

Figure 6. Nyquist plots for pure $\mathrm{Pb}$ and $\mathrm{Pb}-\mathrm{Mg}$ alloys, in a $4 \mathrm{M} \mathrm{H}_{2} \mathrm{SO}_{4}$ solution, measured at $\mathrm{E}_{\text {corr }}$, at $25^{\circ} \mathrm{C}$.

Table 3 presents $R_{t}$ and $C_{d l}$ values, which are estimated from the impedance data at $\mathrm{E}_{\text {corr }}$ of $\mathrm{Pb}$ and $\mathrm{Pb}-\mathrm{Mg}$ alloys. It is observed that $\mathrm{R}_{\mathrm{t}}$ values increase, while $\mathrm{C}_{\mathrm{dl}}$ values decrease with an increasing $\mathrm{Mg}$ content in the alloy. Accordingly, the results show that the corrosion resistance of $\mathrm{Pb}-\mathrm{Mg}$ alloy is superior to that of pure $\mathrm{Pb}$ in $4 \mathrm{M} \mathrm{H}_{2} \mathrm{SO}_{4}$, and that $\mathrm{Pb}-1.5 \% \mathrm{Mg}$ alloy gives higher corrosion resistance. The superior corrosion resistance observed for the investigated alloy, compared 
with pure $\mathrm{Pb}$, could be explained by the barrier protection mechanism theory, in which a barrier acts to prevent further attack by increasing the micro-hardness. This alloy is considered a stable alloy.

Table 1. Corrosion parameters obtained from Tafel plots for pure $\mathrm{Pb}$ and $\mathrm{Pb}-\mathrm{Mg}$ alloys in $4 \mathrm{M} \mathrm{H}_{2} \mathrm{SO}_{4}$, at different temperatures.

\begin{tabular}{|c|c|c|c|c|}
\hline Mg content & $\begin{array}{c}\text { Temperature } \\
\text { (K) }\end{array}$ & $\begin{array}{l}\mathbf{E}_{\text {corr1 }} \\
(\mathbf{m V})\end{array}$ & $\begin{array}{c}I_{\text {corr }} \\
\left(\mu \mathrm{A} / \mathbf{c m}^{2}\right)\end{array}$ & $\begin{array}{l}\text { Corrosion rate } \\
(\text { (mm/year) }\end{array}$ \\
\hline \multirow{4}{*}{ Pure $\mathbf{P b}$} & 298 & -462 & 349 & 41.62 \\
\hline & 318 & -459 & 360 & 44.90 \\
\hline & 338 & -451 & 429 & 49.93 \\
\hline & 358 & -447 & 469 & 53.58 \\
\hline \multirow{4}{*}{$0.5 \% \mathrm{Mg}$} & \begin{tabular}{|l|}
298 \\
\end{tabular} & -471 & 300 & 30.14 \\
\hline & 318 & -462 & 314 & 33.54 \\
\hline & 338 & -454 & 326 & 35.75 \\
\hline & 358 & -447 & 337 & 40.85 \\
\hline \multirow{4}{*}{ 0.8\%Mg } & 298 & \begin{tabular}{|l|}
-498 \\
\end{tabular} & 274 & 20.92 \\
\hline & 318 & -484 & 277 & 23.17 \\
\hline & 338 & -472 & 280 & 25.42 \\
\hline & 358 & -469 & 289 & 29.17 \\
\hline \multirow{4}{*}{$1 \% \mathrm{Mg}$} & \begin{tabular}{|l|}
298 \\
\end{tabular} & $\begin{array}{l}-500 \\
\end{array}$ & 116 & 08.02 \\
\hline & 318 & -483 & 119 & 09.22 \\
\hline & 338 & -474 & 128 & 10.84 \\
\hline & 358 & -466 & 130 & 11.98 \\
\hline \multirow{4}{*}{$1.5 \% \mathrm{Mg}$} & 298 & \begin{tabular}{|l|}
-573 \\
\end{tabular} & 59 & 03.91 \\
\hline & 318 & -561 & 65 & 04.30 \\
\hline & 338 & -552 & 69 & 05.75 \\
\hline & 358 & -547 & 73 & 06.83 \\
\hline
\end{tabular}

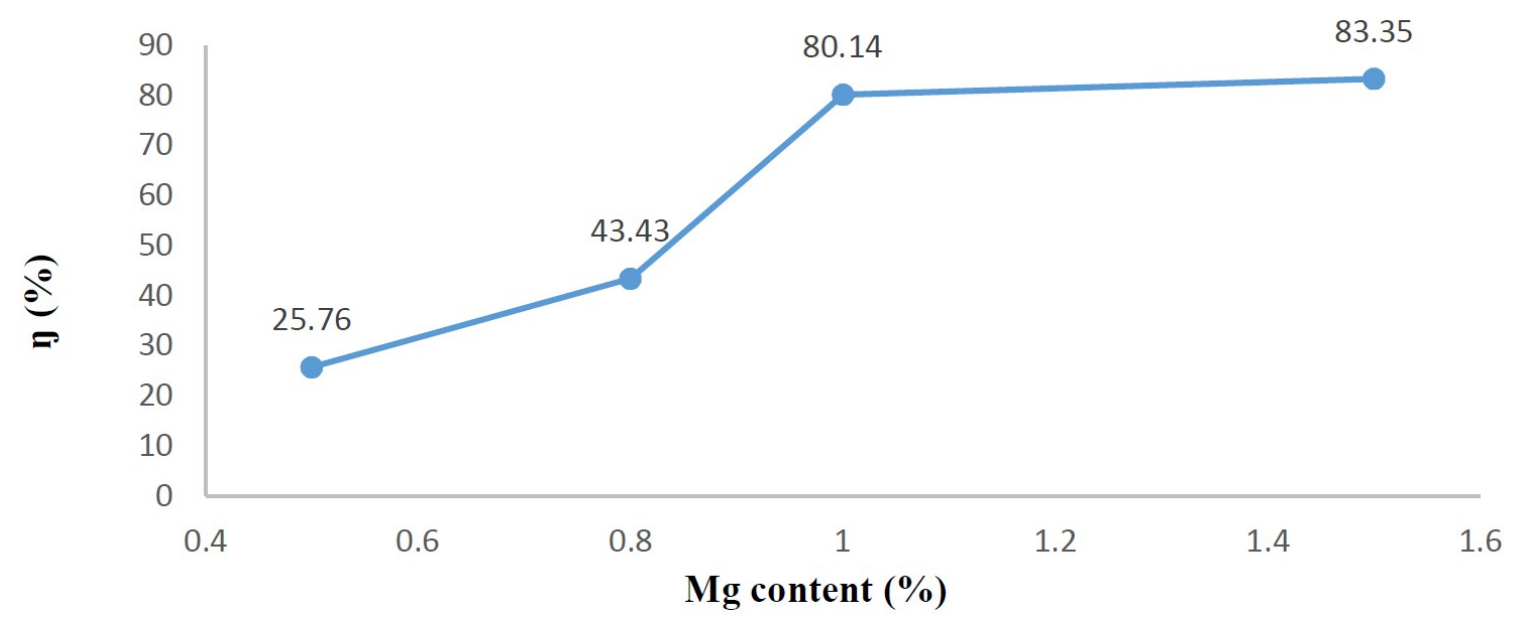

Figure 7. Relationship between $\mathrm{Mg}$ content and inhibition efficiency based on EIS parameters.

As previously found [19], once the lead alloy has been covered by the $\mathrm{PbSO}_{4}$ layer, the attack on it is chiefly determined, at first, by the rate at which the $\mathrm{Pb}^{2+}$ ions diffuse from the $\mathrm{PbSO}_{4}$ layer to the bulk solution; and then, upon complete saturation of the solution, by the much slower growth rate of the compact layer of 
$\mathrm{PbSO}_{4}$ precipitated on lead, protecting it from severe attack of sulfuric acid and, therefore, reducing its corrosion.

The corrosion inhibition efficiency was calculated from the EIS parameters, (Fig. 7), which are in accordance with those of the potentiodynamic polarization.

Effect of temperature on the corrosion of pure $\mathrm{Pb}$ and $\mathrm{Pb}-\mathrm{Mg}$ alloys

Knowing that, inside a Pb-acid battery, temperature can achieve $358 \mathrm{~K}\left(80^{\circ} \mathrm{C}\right)$, we analysed the data to get electrochemical parameters at different temperatures (Table 4). These data show that the corrosion current density ( $\left.\mathrm{I}_{\text {corr }}\right)$ and the corrosion rate values increased with higher temperatures, for both pure $\mathrm{Pb}$ and $\mathrm{Pb}$ Mg alloys.

Table 2. Activation energy $\left(\mathrm{E}_{\mathrm{a}}\right)$ values in $\mathrm{kJ} / \mathrm{mol}$, for $\mathrm{Pb}$ and $\mathrm{Pb}-\mathrm{Mg}$ alloys in $4 \mathrm{M} \mathrm{H}_{2} \mathrm{SO}_{4}$.

\begin{tabular}{cc}
\hline Mg content & $\begin{array}{c}\text { Ea } \\
(\mathrm{kJ} / \mathbf{m o l})\end{array}$ \\
\hline Pure $\mathbf{P b}$ & 3.82 \\
\hline Pb-0.5\%Mg & 4.30 \\
\hline Pb-0.8\%Mg & 4.80 \\
\hline Pb-1\%Mg & 6.06 \\
\hline Pb-1.5\%Mg & 8.64 \\
\hline
\end{tabular}

In an acidic solution, the logarithm of the corrosion rate is a linear function of $1 / \mathrm{T}$ (Arrhenius-type equation [20]. Fig. 8 is shown according to the Arrhenius plots for the corrosion of pure $\mathrm{Pb}$ and its investigated alloys, by plotting $\log \mathrm{CR}$ ( $\mathrm{mm} /$ year) against $1 / \mathrm{T}$.

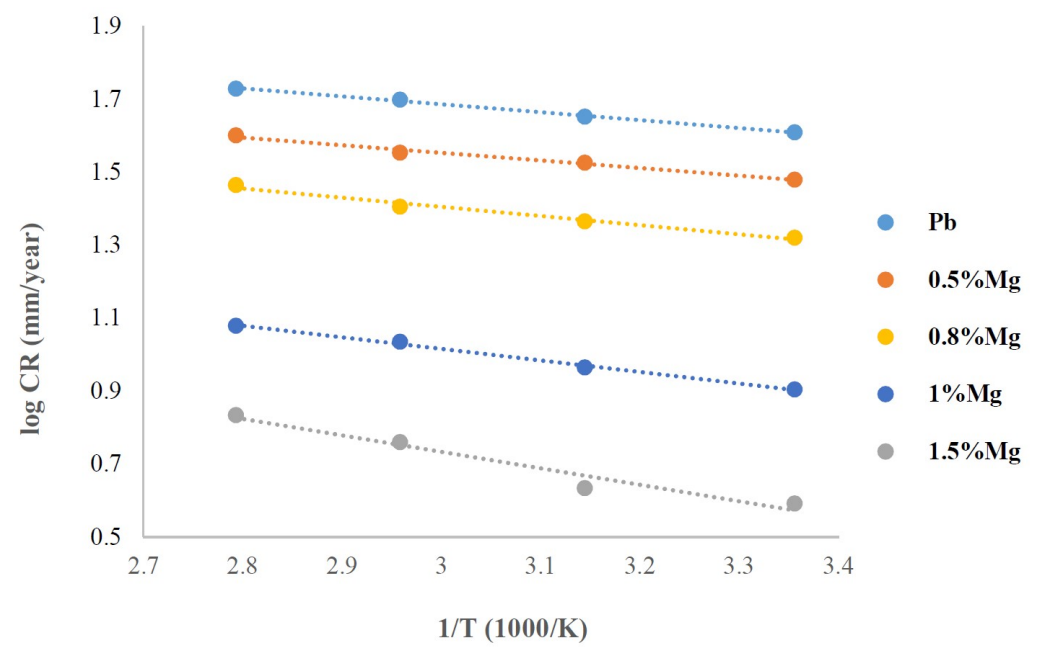

Figure 8. Arrhenius plots for corrosion of pure $\mathrm{Pb}$ and $\mathrm{Pb}-\mathrm{Mg}$ alloys in $4 \mathrm{M} \mathrm{H}_{2} \mathrm{SO}_{4}$ using corrosion rate vs $1 / \mathrm{T}$.

The activation energy for corrosion can be obtained by Arrhenius equation:

$$
\log (C R)=\frac{-E a}{2.303 R T}+A
$$

where $\mathrm{E}_{\mathrm{a}}$ is the activation energy of the pure $\mathrm{Pb}$ and $\mathrm{Pb}-\mathrm{Mg}$ alloys dissolution reaction, $\mathrm{R}$ is the general gas constant and $\mathrm{A}$ is the Arrhenius pre-exponential 
factor. In all cases studied, a plot of the logarithm of corrosion current density vs $1 / T$ resulted in straight lines, with a slope $-\mathrm{E}_{\mathrm{a}} / 2.303 \mathrm{R}$. The resulted plots are shown in Fig. 8, and all calculated activation energies for the pure $\mathrm{Pb}$ and $\mathrm{Pb}-\mathrm{Mg}$ alloys are given in Table 4.

Fig. 8 and Table 4 show that the $\mathrm{E}_{\mathrm{a}}$ values of $\mathrm{Pb}-\mathrm{Mg}$ alloys, in a $4 \mathrm{M} \mathrm{H}_{2} \mathrm{SO}_{4}$ solution, are much higher than that of pure $\mathrm{Pb}$. This behaviour is attributed to the presence of a solid-solution phase which enhanced the activation energy barrier of the corrosion, thus reducing the corrosion rate of the alloy [21]. The higher $\mathrm{E}_{\mathrm{a}}$ values determined for the alloys can be ascribed to the lower active sites and/or to a decrease in anodic to cathodic area ratio [22]. The presence of the single phase in the alloy not only makes a lower rate of the hydrogen evolution reaction, but also inhibits it. It is claimed in the literature that the formation of this single phase in the alloy provides the best protection with the lowest self-corrosion rate [23]. These $\mathrm{E}_{\mathrm{a}}$ values support this trend of the corrosion rate obtained for $\mathrm{Pb}$ and its studied alloys, as mentioned before.

\section{Conclusions}

In this framework, the effect of $\mathrm{Mg}$ content on both micro-hardness and crystallite structure of the $\mathrm{Pb}-\mathrm{Mg}$ alloy was investigated. The corrosion resistance of the mentioned alloys in a $\mathrm{H}_{2} \mathrm{SO}_{4}$ solution was studied by potentiodynamic polarization, as well as by EIS. Several conclusions can be extracted from these investigations:

- The micro-hardness increases, while the crystallite size decreases with increasing magnesium content in the alloy. This trend is attributed to the refinement of the crystalline size and lattice distortion by the addition of magnesium. $\mathrm{Pb}-\mathrm{Mg}$ alloy is much harder and resistant to mechanical shocks than pure $\mathrm{Pb}$.

- $\mathrm{Pb}-\mathrm{Mg}$ alloys have good corrosion resistance in a $4 \mathrm{M} \mathrm{H}_{2} \mathrm{SO}_{4}$ solution, compared with that of pure $\mathrm{Pb}$. Addition of $1.5 \%$ in weight of $\mathrm{Mg}$ led to a decrease in the corrosion rate by $83 \%$. This behavior can be interpreted on the basis that the solute content tends to refine the micro-structure array. Since this alloy is very stable, the passive layer formed with $\mathrm{PbSO}_{4}$ and $\mathrm{PbO}$ is blocking the sites of dissolution reactions.

- Potentiodynamique polarization results showed a corrosion potential ( $\left.E_{\text {corr }}\right)$ towards negative values and a significant reduction of the corrosion current density ( $\mathrm{I}_{\text {corr }}$ ). This means that the corrosion rate decreased and that the corrosion resistant of $\mathrm{Pb}-\mathrm{Mg}$ alloys, compared to that of pure $\mathrm{Pb}$, is higher.

- The results of both Tafel plots extrapolation and EIS measurements exhibited the same trend that the corrosion rate on the alloy surface is less significant compared with that on the surface of pure $\mathrm{Pb}$, and that $\mathrm{Pb}-1.5 \% \mathrm{Mg}$ yielded the best resistance to corrosion in $4 \mathrm{M} \mathrm{H}_{2} \mathrm{SO}_{4}$.

- The corrosion rate of lead and its investigated alloys increases with an increasing temperature, while its effect seems to be more pronounced for alloys than that for lead. The activation energy values of the pure lead and its studied alloys were calculated and compared. 


\section{References}

1. Felder A, Prengaman RD. J Metal. 2006;58:28-31.

2. Bullock KR. J Electrochem Soc. 2009;126:360-365.

3. Meissner E. J Power Sources. 1997;67:135-150.

4. Li DG, Zhou GS, Zhang J, et al. Electrochim Acta. 2007;52: 215.

5. Garche J, Döring H, Wiesener L. J Power Sources. 1991;33:213-220.

6. Abd El-Rahman HA, Salih SA, Abd El-Wahab AM. Mat-wiss. u.Werkstofftech. 2011;784:791.

7. Osório WR, Peixoto C, Garcia A. J Power Sources. 2009;194:120.

8. Čekerevac MI, Romhanji E, Cvijović Z, et al. Mater Corros. 2010;61:51.

9. Prengaman RD. J Power Sources. 2001;95:233.

10. Albert L, Chabrol A, Torcheux L, et al. J Power Sources. 1997;67:265.

11. Khatbi S, Gouale Y, Lamiri A, et al. Port Electrochim Acta. 2016;34:293.

12. Khatbi S, Gouale Y, Lamiri A, et al. Port Electrochim Acta. 2018;36:146.

13. Boulahrouf JH. Mater Character. 1990.24:167.

14. El-Sayed A, Essalam MM, Hossnia S, et al. Metal Mater Trans A. 1995;46:176.

15. Refaey SAM, Taha F, Hasanin THA. Electrochim Acta. 2006;51:48.

16. Hongxia L, Zhilin W. Adv Mater Res. 2013;721:104.

17. Morakchi K, Hamel A, Zazoua A. J Ren Ener. 2008;11:362.

18. Larabi L, Harek Y, Traisnel M. J Appl Electrochem. 2004;34:39.

19. Gonzulez JA, Fullru J, Feliu S. Wcrk Korros. 1975;26:10.

20. Kiani MA, Mousavi MF, Ghasemi S, et al. Corros Sci. 2008;50:1045

21 Mohran HS, El-Sayed A, Abd El-Lateef HM. J Solid State Electrochem. 2009;13:90.

22. El-Sayed A, Mohran HS, Abd El-Lateef HM. J Power Sources. 2010;195:36.

23. Fekry AM, Gasser AA, Ameer MM. J App Electrochem. 2010;40:747. 